DOI: https://doi.org/10.24127/ajpm.v10i4.4279

\title{
PENGARUH KEMANDIRIAN DAN MODEL PROBLEM BASED LEARNING BERBANTUAN GOOGLE CLASSROOM TERHADAP KEMAMPUAN PEMAHAMAN KONSEP MATEMATIS
}

\author{
An Nur Ami Widodo ${ }^{1 *}$, Anwar Ardani ${ }^{2}$, Eris Fanny Firdaus ${ }^{3}$ \\ ${ }^{1 *, 2,3}$ Universitas Peradaban, Brebes, Indonesia \\ *Corresponding author. \\ E-mail: $\quad$ amiaqeela@gmail.com $^{\left.{ }^{*}\right)}$ \\ anwarardani3@gmail.com ${ }^{2}$ \\ erisfirdaus88@gmail.com $^{3)}$
}

Received 24 September 2021; Received in revised form 17 November 2021; Accepted 28 December 2021

\begin{abstract}
Abstrak
Kemampuan pemahaman konsep sangat penting untuk meningkatkan kemampuan berpikir tingkat tinggi. Namun, kenyataan dilapangan menunjukkan kemampuan pemahaman konsep matematis mahasiswa pendidikan matematika masih kurang. Penelitian ini bertujuan untuk mengetahui pengaruh kemandirian dan aktivitas model PBL berbantuan google classroom terhadap kemampuan pemahaman konsep. Penelitian ini merupakan penelitian quasi eksperimen dengan desain penelitian One-group posttest-only design. Subjek dalam penelitian ini adalah mahasiswa prodi pendidikan matematika semester $\mathrm{V}$ Universitas Peradaban sejumlah 16. Teknik pengumpulan data penelitian ini menggunakan angket observasi dan tes. Teknik analisis data penelitian ini adalah uji regresi. Hasil penelitian ini adalah terdapat pengaruh antara kemandirian dan aktivitas pada model PBL berbantuan google classroom terhadap kemampuan pemahaman konsep. Besar pengaruh antara kemandirian dan kemampuan pemahaman konsep sebesar $92,3 \%$.
\end{abstract}

Kata kunci: Kemampuan pemahaman konsep matematis; kemandirian; model problem based learning berbantuan google classroom.

\begin{abstract}
The ability to understand concepts is very important to improve higher order thinking skills. However, the reality on the ground shows that the ability to understand mathematical concepts of mathematics education students is still lacking. This study aims to determine the effect of independence and activity of the PBL model assisted by Google Classroom on the ability to understand concepts. This research is a quasi-experimental research with One-group posttest-only research design. The subjects in this study were 16 students of the fifth semester of the mathematics education study program at the University of Civilization. The data collection techniques used in this research were observation questionnaires and tests. The data analysis technique of this research is regression test. The results of this study are that there is an influence between independence and activity in the PBL model assisted by Google Classroom on the ability to understand concepts. The influence between independence and the ability to understand concepts is $92.3 \%$.
\end{abstract}

Keywords: Ability to understand mathematical concept; google classroom assisted problem based learning model; independence.

This is an open access article under the Creative Commons Attribution 4.0 International License

\section{PENDAHULUAN}

Pemberian permasalahan sangat diperlukan untuk mengembangkan kemampuan matematis. Dalam memecahkan masalah siswa membutuhkan kemampuan pemahaman 
konsep. ...Menurut Afridiani et al. (2020), Pemahaman konsep akan mempermudah siswa memahami pelajaran dan menyelesaikan permasalahan dengan konsep yang sesuai. Sedangkan menurut Tristanti (2017), siswa tidak hanya sekedar tahu (knowing) dan hafal (memorizing) konsep-konsep matematika, namun siswa juga harus mengerti dan memahami (to understand) konsep matematika tersebut serta menghubungkan keterkaitan antara satu konsep dengan konsep lain. Kemampuan pemahaman konsep adalah salah satu kemampuan yang menggunakan konsep yang ada dan mengkaitkan antara satu dengan yang lain untuk memahami dan memecahkan permasalahan.

Kemampuan pemahaman konsep sangat penting untuk meningkatkan kemampuan berpikir tingkat tinggi. Namun, kenyataan dilapangan menunjukkan kemampuan pemahaman konsep matematis mahasiswa pendidikan matematika masih kurang. Hal ini terlihat dari hasil wawancara yang menghasilkan bahwa mahasiswa belum mampu mengklasifikasikan konsep yang dapat digunakan untuk menyelesaikan permasalahan, sehingga mahasiswa keliru dalam menerapkan konsep tersebut dalam memecahkan masalah. Selain itu, sebagian besar mahasiswa belum mampu mengkaitkan kosep yang satu dengan yang lainnya.

Hal ini disebabkan karena mahasiswa masih belum memahami permasalahan dan konsep materi yang diberikan. Mahasiswa masih belum beradaptasi dengan adanya pembelajaran daring sehingga terkadang mahasiswa tidak fokus saat perkuliahan dan pasif saat perkuliahan berlangsung. Selain itu, mahasiswa terbiasa mengandalkan teman untuk menyelesaikan permasalahan di luar kelas. Dosen juga belum menemukan model pembelajaran yang tepat dan masih mencari platform yang efektif digunakan dalam pembelajaran.

Model Problem Based Learning (PBL) merupakan model yang dapat mengembangkan kemampuan mahasiswa dengan memberikan permasalahan diawal pembelajaran. Hal ini sejalan dengan beberapa penelitian menunjukkan bahwa pengaruh aktivitas siswa yang menggunakan model pembelajaran PBL terhadap kemampuan pemahaman konsep matematis (Dalim et al., (2019); Afridiani et al. (2020); Rahmadani \& Acesta (2017)). Oleh karena itu, dapat disimpukan bahwa model PBL dapat digunakan untuk mengembangkan kemampuan pemahaman konsep matematis.

Model PBL dalam penelitian ini diterapkan melalui pembelajaran jarak jauh (online). Pembelajaran jarak jauh masih diterapkan untuk menekan jumlah lonjakan penyebaran covid 19 . Oleh karena itu, model PBL harus dibantu dengan platform yang tepat. Salah satu platform yang dapat digunakan adalah google classrom. Hal ini sejalan dengan penelitian Amalia et al. (2021) yang menyebutkan bahwa kemampuan pemahaman konsep siswa yang diajarkan dengan model PBL berbantu google classroom lebih baik dari kemampuan pemahaman konsep matematis siswa yang yang diajar dengan whatsapp. Penelitian lain menyebutkan bahwa model PBL berbantuan Google Classroom meningkatkan prestasi belajar dan dapat membantu guru memberikan materi pembelajaran, tugas, dan ujian, mudah digunakan dan dapat dipantau secara realtime (Krisna \& Marlinda (2020); Muslik (2019)). Berdasarkan penelitian 
terdahulu dapat disimpulkan bahwa penerapan model PBL berbantuan google classroom dapat meningkatkan prestasi belajar. Sedangkan penggunaan google classroom lebih baik dari whatapps group.

Hal yang baru dalam penelitian ini adalah menerapkan model PBL berbantuan google classroom untuk meningkatkan kemampuan pemahaman konsep. Selain model pembelajaran fokus lain yang dilihat adalah kemandirian mahasiswa dalam pembelajaran. Penelitian ini digunakan untuk melihat seberapa besar pengaruh kedua faktor tersebut. Mahasiswa selama ini hanya diberikan masalah oleh dosen. Sedangkan penelitian ini akan menuntut mahasiswa menemukan masalah sendiri dan menyelesaikannya sehingga diharapkan berpengaruh terhadap kemampuan pemahaman konsep matematisnya. Hal ini sejalan dengan hasil penelitian yang menunjukkan bahwa meningkatnya kemandirian belajar akan meningkatkan kemampuan pemahaman konsep matematika (Risqilah (2015); Winata et al. (2021)).

Berdasarkan latar belakang diatas, penelitian ini bertujuan untuk mengetahui pengaruh kemandirian dan aktivitas model PBL berbantuan google classroom terhadap kemampuan pemahaman konsep.

\section{METODE PENELITIAN}

Penelitian ini merupakan penelitian quasi eksperimen. Desain penelitian menggunakan One-group posttest-only design (Hastjarjo, 2019). Tahapan penelitian ini adalah (1) melakukan identifikasi masalah, (2) menentukan solusi permasalahan, (3) merumuskan masalah,(4) mengumpulkan teori yang mendukung, (5) menentukan metode penelitian, (6) melakukan perlakuan yaitu dengan model PBL berbantuan google classroom, (7) menyiapkan instrumen penelitian, (8) melakukan pengumpulan data penelitian, (9) analisis data, (10) penarikan kesimpulan.

Model PBL berbantuan google classroom dilakukan dengan membuat instrumen soal matematika, materi sesuai dengan pembagian tugas. Soal tersebut diberikan kepada siswa SMP/SMA/SMK di sekolah. Setelah dikerjakan mahasiswa melakukan analisis validitas, reliabilitas, tingkat kesukaran dan daya pembeda dari jawaban siswa.

Subjek yang digunakan dalam penelitian ini adalah mahasiswa prodi pendidikan matematika semester $\mathrm{V}$ Universitas Peradaban sejumlah 16 mahasiswa. Pembelajaran menggunakan model Problem Based Learning pada mata kuliah Evaluasi Hasil Pembelajaran.

Teknik pengumpulan data penelitian ini menggunakan angket observasi dan tes. Angket digunakan untuk mengetahui kemandirian mahasiswa dalam pembelajaran. Sedangkan tes digunakan untuk mengetahui kemampuan pemahaman konsep matematis. Angket dan tes di buat sesuai dengan indikator kemandirian belajar dan kemampuan pemahaman konsep matematis. Observasi digunakan untuk mengetahui aktivitas mahasiswa saat pembelajaran dengan model PBL berbantuan Google classroom. Jumlah butir soal tes ada 5 soal dan 20 butir soal angket.

Sebelum dilakukan penyebaran angket dan tes, maka dilakukan uji validitas, reliabilitas, tingkat kesukaran, dan daya pembeda (Yusup, 2018). Analisis hasil uji coba tes menghasilkan 5 soal tergolong valid, 1 soal tidak valid, dan soal realibel. 
Tingkat kesukaran tes adalah 1 soal kriteria tinggi, 3 soal kriteria sedang, dan 2 soal dengan kriteria rendah. Daya pembeda soal 1 soal yang ditolak dan 5 soal diterima. berdasarkan analisis maka dari 6 soal yang di buat, 5 soal yang dapat digunakan.

Teknik analisis data penelitian ini adalah uji regresi. Hasil angket kemandirian dan aktivitas model digunakan sebagai variabel $x$ (Independent Variable) dan hasil tes kemampuan pemahaman konsep sebagai variabel $y$ (Dependent Variable). Dengan uji regresi akan di uji pengaruh antara variabel $\mathrm{x}$ terhadap $\mathrm{y}$ dan dapat diketahui seberapa besar pengaruh kemandirian dan model PBL berbantuan google classroom terhadap kemampuan pemahaman konsep.

\section{HASIL DAN PEMBAHASAN}

Pembelajaran mata kuliah evaluasi hasil belajar dalam penelitian ini menggunakan model PBL. Langkahlangkah pembelajaran dengan model PBL dalam penelitian ini (Rahmadani, 2019) adalah sebagai berikut.

1. Orientasi mahasiswa pada masalah: dosen memberikan permasalahan dan mahasiswa membuat permasalahan yang berkaitan dengan materi pembelajaran.

2. Mengorganisasi mahasiswa untuk belajar: dosen memberikan pengarahan tentang tugas belajar siswa berkenaan dengan masalah tersebut.

3. Membimbing penyelidikan individu/ kelompok: Mahasiswa membuat soal, kemudian memberikan soal tersebut kepada siswa dan melakukan analisis terhadap hasil jawaban siswa.

4. Mengembangkan dan menyajikan hasil karya: mahasiswa mempresentasikan hasil pembuatan soal dan analisisnya.
5. Menganalisis dan mengevaluasi proses pemecahan masalah : dosen dan mahasiswa melakukan refleksi dan evaluasi terhadap hasil karya nya

Setelah pembelajaran berakhir, angket kemandirian belajar dan tes kemampuan pemahaman konsep matematis diberikan kepada mahasiswa. Kemudian data yang diperoleh dianalis menggunakan uji regresi linier berganda menggunakan SPSS 23.

Uji prasyarat sebelum dilakukan uji regresi linier berganda adalah uji normalitas dan uji linieritas. Uji normalitas menggunakan uji shapiro wilk. Hasil uji shapiro wilk dapat dilihat pada Tabel 1.

Tabel 1. Uji normalitas shapiro wilk

\begin{tabular}{|c|c|c|c|}
\hline & \multicolumn{3}{|c|}{ Shapiro-Wilk } \\
\hline & Statistic & $d f$ & Sig. \\
\hline $\begin{array}{l}\text { Pemahaman } \\
\text { konsep }\end{array}$ & 0,942 & 16 & 0,377 \\
\hline Kemandirian & 0,930 & 16 & 0,239 \\
\hline $\begin{array}{l}\text { Aktivitas__ } \\
\text { ModelPBL }\end{array}$ & 0,949 & 16 & 0,480 \\
\hline
\end{tabular}

Hipotesis :

Ho : variabel terdistribusi normal

Ha : variabel tidak terdistribusi normal

Berdasarkan hasil uji shapiro wilk, nilai signifikan data pemahaman konsep sebesar $0,377>\alpha=0,05$, maka Ho ditolak artinya variabel pemahaman konsep berdistribusi normal. Sedangkan nilai signifikan data kemandirian sebesar $0,239>\alpha=0,05$, maka Ho ditolak artinya variabel kemandirian berdistribusi normal. Untuk nilai signifikan data aktivitas dengan model PBL sebesar 0,480 $>\alpha=0,05$, maka Ho ditolak artinya variabel aktivitas dengan model PBL berdistribusi normal. 
DOI: https://doi.org/10.24127/ajpm.v10i4.4279

Selain uji normalitas, dilakukan uji linieritas. Hasil uji linieritas dapat dilihat pada Tabel 2.

Tabel 2. Uji linieritas

\begin{tabular}{lc}
\hline & $\begin{array}{c}\text { Sig. } \\
\text { Liniearity }\end{array}$ \\
\hline $\begin{array}{l}\text { Pemahaman } \\
\text { konsep*Kemandirian }\end{array}$ & 0,177 \\
$\begin{array}{l}\text { Pemahaman } \\
\text { konsep*Aktivitas model PBL }\end{array}$ & 0,063 \\
\hline
\end{tabular}

Berdasarkan hasil uji linieritas menunjukkan bahwa Sig. Liniearity untuk kemandirian sebesar $0,177>\alpha=$ 0,05 , artinya terdapat hubungan linier antara pemahaman konsep dengan kemandirian. Sedangkan Sig. Liniearity untuk aktivitas dengan model PBL sebesar $0,063>\alpha=0,05, \quad$ artinya terdapat hubungan linier antara pemahaman konsep dengan aktivitas dengan model PBL.

Terlihat dari kedua uji prasyarat terpenuhi, sehingga dapat dilakukan uji regresi linier berganda. Hipotesis uji regresi linier berganda dalam penelitian ini adalah sebagai berikut.

Ho: tidak terdapat pengaruh antara kemandirian dan aktivitas pada model PBL berbantuan google classroom terhadap kemampuan pemahaman konsep.

H1: terdapat pengaruh antara kemandirian dan aktivitas pada model PBL berbantuan google classroom terhadap kemampuan pemahaman konsep.

Hasil analisis uji regresi linier berganda dapat dilihat dari Tabel 3.

Tabel 3. Hasil uji regresi linier berganda

\begin{tabular}{llr|r|r|r|r}
\hline & Model & Sum of Squares & df & Mean Square & \multicolumn{1}{c}{ F } & \multicolumn{1}{c}{ Sig. } \\
\hline 1 & Regression & 1029.979 & 2 & 514.989 & 78.055 & $.000^{\mathrm{b}}$ \\
Residual & 85.771 & 13 & 6.598 & & \\
Total & 1115.750 & 15 & & & \\
\hline
\end{tabular}

Terlihat pada Tabel 3, nilai signifikan adalah 0,000. Nilai signifikan kurang dari 0,05 sehingga Ho ditolak. Jadi, kesimpulannya adalah terdapat pengaruh antara kemandirian dan aktivitas pada model PBL berbantuan google classroom terhadap kemampuan pemahaman konsep.

Hal ini sejalan dengan pembelajarannya. Model PBL berbantuan google classroom yang di terapkan dalam pembelajaran dan kemandirian yang dimiliki membuat mahasiswa lebih mengembangkan kemampuan pemahaman konsep mahasiswa. Mahasiswa di tuntut untuk membuat permasalahan sendiri yaitu membuat instrumen soal yang diberikan secara berkelompok kepada siswa di sekolah. Setiap mahasiswa dalam kelompok dibagi tugas yang sama sehingga kemandirian setiap mahasiswa terbentuk. Kemudian hasil tes di nilai dan di analisis. Hal ini membuat mahasiswa menggunakan teori yang telah diperoleh untuk menganalisis hasil tes. Setalah itu, mahasiswa mempresentasikan hasil kerjanya. Setiap mahasiswa dalam kelompok diberi kesempatan yang sama untuk memberikan pendapat. dalam pembelajaran dapat terlihati bahwa kemandirian yang dimiliki dan aktivitas yang dilakukan berpengaruh terhadap kemampuan pemahaman konsep mahasiswa.

Pada Tabel 4 dapat dilihat persamaan regresinya. 
DOI: https://doi.org/10.24127/ajpm.v10i4.4279

Tabel 4. Coefficients

\begin{tabular}{|c|c|c|c|c|c|}
\hline \multirow[b]{2}{*}{ Model } & \multicolumn{2}{|c|}{$\begin{array}{c}\text { Unstandardized } \\
\text { Coefficients }\end{array}$} & \multirow{2}{*}{\begin{tabular}{|c|}
$\begin{array}{c}\text { Standardized } \\
\text { Coefficients }\end{array}$ \\
Beta
\end{tabular}} & \multirow[b]{2}{*}{$t$} & \multirow[b]{2}{*}{ Sig. } \\
\hline & B & Std. Error & & & \\
\hline $\begin{array}{ll}1 \text { (Constant }) \\
\end{array}$ & -19.825 & 9.391 & & -2.111 & .055 \\
\hline kemandirian & .284 & .501 & .179 & .567 & .580 \\
\hline aktivitas_model_PBL & .932 & .375 & .786 & 2.483 & .027 \\
\hline
\end{tabular}

Persamaan regresi dalam penelitian ini adalah $\hat{y}=-19,825+$ $0,284 x_{1}+0,932 x_{2}$. Dari persamaan tersebut dapat disimpulkan bahwa terdapat pengaruh positif dari kemandirian dan aktivitas model PBL berbantuan google classroom terhadap kemampuan pemahaman konsep.

Hal ini terlihat pada saat pembelajaran pengaruh kemandirian dan aktivitas model PBL berbantuan google classroom positif. Mahasiswa yang kemandirian dan aktivitasnya kurang maka kemampuan yang berkembang kurang. Ada beberapa mahasiswa yang tidak melakukan tugas dalam kelompoknya dan pasif dalam pembelajaran maka akan berpengaruh terhadap kemampuannya. Sebaliknya mahasiswa yang mandiri dan aktif lebih tinggi kemampuannya.

Seberapa besar pengaruh faktor tersebut dapat dilihat pada Tabel 5.

Tabel 5. R square uji regresi linier berganda

\begin{tabular}{rr|r|r|r}
\hline Model & $\boldsymbol{R}$ & $\boldsymbol{R}$ Square & \multicolumn{1}{c}{ Adjusted R Square } & Std. Error of the Estimate \\
\hline 1 & $.961^{\mathrm{a}}$ & .923 & .911 & 2.569 \\
\hline
\end{tabular}

Nilai $R$ square pada Tabel 3 adalah 0,887. Artinya, besar pengaruh antara kemandirian dan kemampuan pemahaman konsep sebesar 92,3\%. Hasil tersebut sejalan dengan penerapan model PBL berbantuan google classroom. Dengan pemberian masalah dan pembuatan masalah sendiri oleh mahasiswa dapat membuat mahasiswa terjun langsung dalam menemukan permasalahan sehingga mahasiswa lebih mudah memahami masalah. Masalah yang dibuat adalah soal matematika yang diberikan kepada siswa di sekolah dan setelah itu dilakukan analisis hasil dari soal tersebut. Mahasiswa dapat mengetahui dan memahami lebih mendalam tentang masalah tersebut. Mahasiswa dituntut untuk bekerja secara mandiri dalam mencari informasi yang tepat untuk menyelesaikan permasalahan.
Selain itu dengan berbantuan google classroom dapat membantun mahasiswa untuk mendiskusikan permasalahan dalam kelompok dan mempresentasikan hasil karyanya dalam pembelajaran. Mahasiswa dapat memperoleh informasi dari kelompok lain mengenai permasalahan kelompok lain dan penyelesaiannya. Hal tersebut dapat membuat mahasiswa mengetahui banyak masalah dan solusinya. Sehingga kemampuan pemahaman konsep mahasiswa dapat berkembang.

Kelebihan dalam penelitian ini adalah model PBL berbantuan google classroom dapat membuat mahasiswa dapat menyelesaikan permasalahan yang ada dengan teori yang telah dipelajari. Saat mempresentasikan hasil karya setiap mahasiswa dapat memperoleh informasi dari kelompok lain sehingga pemahaman terhadap 
materi semakin besar. Mahasiswa diberi kesempatan untuk langsung memberikan soal kepada siswa di sekolah, sehingga mahasiswa melakukan analisis data yang nyata hasil tes siswa.

Kelemahan dalam penelitian ini adalah masih ada beberapa masiswa yang pasif dalam pembelajaran yaitu belum berani mengungkapkan pendapat saat presentasi maupun tanya jawab, terdapat mahasiswa yang kurang kinerjanya dalam kelompok. Hal ini dapat perbaiki dengan memberikan instrumen penilaian tiap kelompok sehingga setiap anggota kelompok dapat memberikan penilaian terhadap anggota lainnya.

Hal ini diperkuat dengan beberapa hasil penelitian yang relevan. Terdapat pegaruh interaktif yang signifikan model PBL dan Kemandirian Belajar terhadap pemahaman konsep matematika (Sodri, 2018). Menurut Muhamad (2018) meningkatkan pemahaman konsep matematika dapat dilakukan dengan meningkatkan kemandirian belajar dan perhatian orang tua. Selain itu, menurut (Afridiani et al., 2020) pengaruh model PBL berbasis lembar kerja peserta didik terhadap kemampuan pemahaman konsep matematis.

Implikasi dalam penelitian ini adalah kemandirian dan model PBL berbantuan google classroom dapat melatih dan mengembangkan kemampuan pemahaman konsep mahasiswa. Mahasiswa dituntut untuk menyelesaikan masalah sesuai dengan konsep yang dimilikinya dan mempresentasikan hasil karyanya.

\section{KESIMPULAN DAN SARAN}

Berdasarkan hasil penelitian, dapat disimpulkan bahwa terdapat pengaruh antara kemandirian dan aktivitas pada model PBL berbantuan google classroom terhadap kemampuan pemahaman konsep. Besar pengaruh antara kemandirian dan kemampuan pemahaman konsep sebesar 92,3\%.

Saran dalam penelitian ini adalah penggunakan faktor lain untuk meningkatkan kemampuan pemahaman konsep. Penerapan model PBL dapat ditambah dengan variabel lain misalnya etnomatematika, RME, Scaffolding, kontekstual, dan lain sebagainya.

\section{DAFTAR PUSTAKA}

Afridiani, T., Soro, S., \& Faradillah, A. (2020). Pengaruh Model Problem Based Learning (PBL) Berbasis Lembar Kerja Peserta Didik (LKPD) Terhadap Kemampuan Pemahaman Konsep Matematis. Euclid, $\quad 7(1), \quad 12$. https://doi.org/10.33603/e.v7i1.25 32

Amalia, S. R., Purwaningsih, D., \& Utami, W. B. (2021). Problem Based Learning Berbantu Google Classroom terhadap Kemampuan Pemahaman Konsep Matematis. Aksioma: Jurnal Program Studi Pendidikan Matematika, 10(2), 1110-1117.

Dalim, Rosita, C. D., \& Dewi, I. L. K. (2019). Pembelajaran Model Problem Based Learning Terhadap Kemampuan Pemahaman Konsep Matematis Siswa. Snpm, 1(1), 166-173.

Dicky Hastjarjo. (2019). Rancangan Eksperimen-Kuasi QuasiExperimental Design. Buletin Psikologi, 27(2), 187-203. https://doi.org/10.22146/buletinps ikologi.38619

Krisna, E. D., \& Mery Marlinda, N. L. P. (2020). Implementasi Problem Based Learning berbantuan Google Classroom Untuk Meningkatkan Prestasi Belajar 
DOI: https://doi.org/10.24127/ajpm.v10i4.4279

Matematika. PENDIPA Journal of Science Education, 4(3), 91-97. https://doi.org/10.33369/pendipa.4 .3.91-97

Muhamad, I. (2018). Pengaruh Kemandirian Belajar dan Perhatian Orang Tuaterhadap Pemahaman Konsep Matematika (Survey Pada SMANegeri Kota Tangerang Selatan). Alfarisi, 1(3), 285-193.

Muslik, A. (2019). Google Classroom sebagai Alternatif Digitalisasi Pembelajaran Matematika di Era Revolusi Industri 4.0. Andragogi: Jurnal Diklat Teknis Pendidikan Dan Keagamaan, 7(2), 246-255. https://doi.org/10.36052/andragog i.v7i2.98

Rahmadani. (2019). Metode Penerapan Model Pembelajaran Problem Based Learnig (Pbl). Lantanida Journal, $\quad 7(1), \quad 75$. https://doi.org/10.22373/lj.v7i1.44 40

Rahmadani, H., \& Acesta, A. (2017). Pengaruh Penerapan Model Pembelajaran Problem Based Learning terhadap Pemahaman Konsep Siswa. 2(1), 1-9.

Risqilah. (2015).

Pengaruh

Kemandirian Belajar Dan Motivasi Belajar Melalui Model Examples Non Examples Terhadap Kemampuan Pemahaman Konsep Materi Kubus dan Balok di MTs. Gondang Wonopringgo. Delta, 3(2), 58-64.

Sodri, S. (2018). Pengaruh Model Pembelajaran dan Motivasi Belajar terhadap Pemahaman Konsep Matematika. Journal of Mathematics Learning, 1(2), 1828.

https://doi.org/10.30653/004.2018 12.18
Tristanti, L. B. (2017). Pengaruh Model Pembelajaran Kooperatif Tipe TAI dan Problem Based Learning (PBL) terhadap Pemahaman Konsep Bangun Ruang Siswa. Aksioma: Jurnal Program Studi Pendidikan Matematika, 6(3), 338-349.

Winata, R., Friantini, R. N., \& ... (2021). E-Learning: Kemandirian Belajar Terhadap Pemahaman Konsep Matematika Pada Pembelajaran dengan Google Classroom. Faktor: Jurnal Ilmiah ..., 8, 148-157. https://journal.lppmunindra.ac.id/i ndex.php/Faktor/article/view/9787

Yusup, F. (2018). Uji Validitas dan Reliabilitas Instrumen Penelitian Kuantitatif. Jurnal Tarbiyah: Jurnal Ilmiah Kependidikan, 7(1), 17-23. https://doi.org/10.18592/tarbiyah. v7i1.2100 